\title{
KEPUASAN PUBLIK DILIHAT DARI \\ KUALITAS PELAYANAN DALAM PENGURUSAN \\ PERIZINAN \\ (KASUS BADAN PELAYANAN PERIZINAN TERPADU, PENGADAAN BARANG DAN JASA KAB. DHARMASRAYA)
}

\author{
Elva Dona \\ STIE “KBP” Padang \\ (mifthah02@gamil.com)
}

\begin{abstract}
ABSTRAK
Tujuan dari penelitian ini adalh untuk mengetahui seberapa besar pengaruh kualitas pelayanan terhadap kepuasan publik dalam pengurusan perizinanpada badan pelayanan perizinan terpadu,pengadaan barang dan jasa kab. Dharmasraya.Populasi dalam penelitian ini adalah jumlah pelanggan pada Badan Pelayanan Perizinan Terpadu, Pengadaan Barang dan Jasa yang mendapat pelayanan jasa pembuatan izin SITU.Hasil penelitian ini menunjukkan bahwa dimensi tangible, empathy, reliability tidak signifikanterhadap kepuasan publik karena nilai signifikannya $>0,05$. Sedangkan dimensi responsiveness dan assurance signifikan terhadap kepuasan publik dalam pengurusan perizinan karena nilai signifikan $<0,05$. Artinya kualitas jasa perlu ditingkatkan untuk mencapai kepuasan publik baik secara langsung maupun tidak langsung.
\end{abstract}

Kata Kunci : Kualitas pelayanan, kepuasan publik

\section{PENDAHULUAN}

Kabupaten Dharmasraya merupakan kabupaten hasil pemekaran dari Kabupaten Sawahlunto Sijunjung sesuai dengan Undang-Undang Nomor 38 Tahun 2003 tentang Pembentukan Kabupaten Dharmasraya, Kabupaten Solok Selatan dan Kabupaten Pasaman Barat Propinsi Sumatera Barat.

Sehubungan dengan Peraturan Pemerintah Nomor 58 Tahun 2005tentang Pengelolaan Keuangan Daerah, maka Pemerintah Kabupaten Dharmasraya mempunyai wewenang dalam mengatur dan mengelola keuangan daerah, yang meliputi penerimaan, pendapatan daerah dan pengeluaran belanja daerah. Khususnya penerimaan, pendapatan daerah dapat berupa pendapatan asli daerah (PAD), dana perimbangan dan lain-lain pendapatan daerah yang syah. Pendapatan asli daerah (PAD) meliputi Pajak Daerah, Retribusi Daerah dan Lain-lain Pendapatan Daerah yang sah.

Dalam rangka untuk mencapai kebutuhan Pemerintah Kabupaten Dharmasraya akan Pendapatan Asli Daerah (PAD) yang berupa Pajak Daerah dan Retribusi Daerah antara lain dengan mengadakan PelayananPengurusan Izin. Di Kabupaten 
Dharmasraya terdapat beberapa Satuan Kerja Perangkat Daerah (SKPD) yang menjadi penghubung dari pengurusan Surat Izin diantaranya Dinas Koperindag, Dinas Kesehatan, Dinas Perhubungan dan Pariwisata, dan Dinas Pertambangan yang semua SKPD tersebut dikoordinasikan Dinas Pendapatan Pengelolaan Keuangan dan Aset Daerah (DPPKA).

Sejak diterbitkannya Peraturan Bupati Nomor 07 Tahun 2008 tentang Pembentukan Struktur Organisasi dan tata Kerja Lembaga Teknis Daerah Kabupaten Dharmasraya yaitu Badan Pelayanan Perizinan Terpadu Pengadaan Barang dan Jasa (BP2TPBJ) demi mewujudkan pelayanan perizinan dan non-perizinan yang prima dengan kemudahan biaya yang transparan serta ketepatan waktu penyelesaian, maka Surat Izin yang dikelola Dinas Koperasi, Industri dan Perdagangan seperti Surat Izin Tempat Usaha (SITU), Surat Izin Usaha Perdagangan (SIUP) dan Tanda Daftar Perusahaan dikelola oleh Badan Pelayanaan Terpadu, Pengadaan Barang dan Jasa, dalam rangka mewujudkan pelayanan prima kepada publik.

Sebagaimana tercantum dalam Keputusan Menteri Pemberdayaan Aparatur Negara Nomor 63/KEP.M.PAN/7/2003 dimana yang dimaksud dengan pelayanan publik adalah "sebagai pemberian layanan (melayani) keperluan orang atau publik yang mempunyai kepentingan pada organisasi itu sesuai dengan aturan pokok dan tata cara yang telah ditetapkan" dan tujuan dari pelayanan publik adalah "Memuaskan dan atau sesuai dengan keinginan publik pada umumnya".

Dengandiberlakukannya otonomi daerah, tugas pokok dan fungsi Badan Pelayanan Perizinan Terpadu, Pengadaan Barang dan Jasa (BP2TPBJ) adalah mengelola semua bentuk pelayanan perizinan dan pengadaan barang dan jasa dengan sistem yang sangat strategis disamping sebagai salah satu inner pengelola sumber pendapatan daerah, sebab investasi baik yang menggunakan fasilitas penanaman modal asing (PMA) maupun modal dalam negeri (PMDN) dan perorangan merupakan pendorong pertumbuhan ekonomi dan pembangunan yang penting untuk pemberdayaan ekonomi publik di Kabupaten Dharmasraya.

Pendapatan Asli Daerah (PAD) yang berupa pajak daerah dan retribusi daerah yang diterima dari publik yang mengurus izin pada Badan Pelayanan Perizinan Terpadu, Pengadaan Barang dan Jasa yang sebagai penghubung bagi Kabupaten Dharmasraya tentu bergantung pada kualitas pelayanan yang diberikan.

Semakin tinggi kualitas pelayanan yang diberikan maka akan semakin tinggi tingkat kepuasan publik dalam mengurus perizinan. Dalam rangka mewujudkan suatu kualitas pelayanan yang baik tentu diperlukan adanya manajemen yang baik pula, karena manajemen merupakan alat untuk mencapai tujuan yang diinginkan dan manajemen yang baik akan memudahkan terwujudnya Pemerintah. Adapun unsur unsur manajemen itu terdiri dari $6 \mathrm{M}$ :man, money, methode, machines, materials, dan market (Hasibuan, 2005).

Selain itu untuk mempertahankan hidupnya, manusia (dalam hal ini adalah publik) sangat memerlukan pelayanan, baik dari diri sendiri maupun karya orang lain. Pelayanan adalah proses pemenuhan kebutuhan melalui aktivitas orang lain secara langsung. Pelayanan yang dibutuhkan manusia ada dua macam, yaitu layanan fisik yang sifatnya pribadi sebagai manusia dan layanan administrasi yang diberikan oleh orang lain selaku anggota organisasi.

Secara umum pada Badan Pelayanan Perizinan Terpadu, Pengadaan Barang dan

Jasa 
(BP2TPBJ) Kabupaten

Dharmasraya kepuasan publik yang merupakan suatu tugas harus dipenuhi bagi semua komponen yang

Adapun yang dimaksud pelayanan umum menurut Keputusan Menteri Pendayagunaan Aparatur Negara No. 81/1993 adalah segala bentuk kegiatan pelayanan umum yang dilaksanakan oleh instansi pemerintah pusat, di daerah, dan di lingkungan Badan Usaha Milik Negara dan Daerah dalam bentuk barang dan atau jasa, baik dalam rangka upaya pemenuhan kebutuhan publik maupun dalam rangka pelaksanan ketentuan peraturan perundang- undangan.

Kualitas merupakan suatu kondisi dinamis, yang berhubungan dengan produk, jasa, manusia, proses dan lingkungan yang memenuhi dan melebihi harapan.

Agar pelayanan dapat memuaskan orang lain yang dilayani, maka pelaku yang bertugas melayani harus memenuhi empat kriteria pokok (Moenir dalam Tangklis, 2007) yaitu :

1) Tingkah laku yang sopan.

2) Cara menyampaikan sesuatu yang berkaitan dengan apa yang seharusnya diterima oleh orang yang bersangkutan.

3) Waktu menyampaikan yang tepat.

4) Keramahtamahan.

Menurut Tjiptono (2000) terdapat 5 (lima) faktor yang menentukan kualitas jasa, yaitu :

1. Tangible (berwujud) yaitu fisik dan jasa, bisa berupa fasilitas fisik, peralatan, personil dan komunikasi harus baik dalam melaksanakan proses perizinan.

2. Empathy (empati) meliputi kemudahan dalam hal melakukan hubungan, komunikasi yang baik, perhatian pribadi dan memahami kebutuhan publik.

3. Reliability (kehandalan) kemampuan memenuhi janji layanan secara cepat, akurat dan memuaskan.

4. Responsivenes (Ketanggapan) merupakan keinginan para staf untuk membantu publik dalam memberikan pelayanan secara tanggap.

5. Assurance (jaminan) mencakup pengetahuan, kemampuan, kesopanan dan keraguraguan.

Setelah melakukan pengamatan awal pada Badan Pelayanan Perizinan Terpadu, Pengadaan Barang dan Jasa (BP2TPBJ) Kabupaten Dharmasraya, terlihat bahwa masih terdapat kelemahan-kelemahan yang perlu diperbaiki dan diperhatikan seperti : sarana dan prasarana yang belum memadai serta kualitas pelayanan masih mendapat keluhan dari publik pengguna layanan perizinan seperti pelayanan yang berbelit-belit, tidak transparan dan biaya tinggi.

Sehubungan dengan hal tersebut, penelitian ini memberikan argumentasi bahwa kualitas pelayanan berhubungan erat dengan tingkat kepuasan publik dalam disiplin ilmu manajemen pelayanan publik. Disamping itu, walaupun sejak berdirinya Badan Pelayanan Perizinan Terpadu, Pengadaan Barang dan Jasa (BP2TPBJ) belum pernah dilakukan penelitian dan analisis terhadap pengaruh kualitas pelayanan terhadap kepuasan publik dalam pengurusan izin, sehingga penelitian ini juga dapat menjadi acuan bagi Pemerintah Kabupaten Dharmasraya dalam menciptakan dan mewujudkan suatu kualitas pelayanan yang baik di masa yang akan datang. 


\section{TINJAUAN PUSTAKA DAN HIPOTESIS}

\section{Jasa (Service)}

Pengertian Jasa

Menurut Kotler dan Amstrong (2001), jasa adalah segala aktivitas atau manfaat yang dapat ditawarkan oleh

satu pihak ke pihak lain, yang pada dasarnya bersifat intangible (tak berwujud-fisik) dan tidak menghasilkan kepemilikan sesuatu. Produk jasa biasa berhubungan dengan produk fisik maupun tidak.

Jasa merupakan aktivitas, manfaat, atau kepuasan yang di tawarkan untuk dijual (Tjiptono, 2004). Jadi jasa adalah sebuah tindakan atau perbuatan yang bersifat intangible yang ditawarkan untuk di jual kepihak lain. Pada umumnya jasa diproduksi dan dikonsumsi secara bersama, dimana interaksi antara pemberi dan penerima jasa akan mempengaruhi hasil dari jasa tersebut (Rangkuti, 2002)

\section{Karakteristik Jasa}

Menurut Tjiptono (2004) ada empat karakteristik pokok pada jasa yang membedakannya dengan barang. Keempat karakteristik tersebut meliputi :

\section{1) Intangible}

Jasa bersifat intangible artinya, tidak dapat dilihat, dirasa, diraba, dicium atau didengar (Enis dan Cok dalam Tjiptono,2004)

Konsep intangible ini sendiri memiliki dua pengertian yaitu :

a. Sesuatu yang tidak dapat disentuh dan tidak dapat dirasa.

b. Sesuatu yang tidak mudah didefinisikan, diformulasikan, atau dipahami secara rohaniah.

Seseorang tidak dapat menilai hasil dari jasa sebelum ia merasakannya sendiri. Bila publik membeli jasa, maka ia hanya menggunakan, memanfaatkan, atau menyewa jasa tersebut. Oleh karena itu untuk mengurangi ketidakpastian, para publik memperhatikan tanda-tanda atau bukti kualitas jasa tersebut. Mereka akan menyimpulkan kualitas jasa dari tempat (place), orang (people), peralatan (equipment), bahan-bahan komunikasi (communication materials), simbol, dan biaya yang mereka bayar.

2) Inseparability

Barang biasanya diproduksi, kemudian dijual, lalu dikonsumsi.Sedangkan jasa biasanya dijual terlebih dahulu, baru kemudian diproduksi dan konsumsi secara bersamaan.Interaksi antara penyedia jasa dan publik merupakan ciri khusus dalam pemasaran jasa.Keduanya mempengaruhi hasil (out come) dari jasa tersebut.Dalam hubungan penyedia jasa dan publik ini, efektivitas individu yang menyampaikan jasa (contact personel) merupakan unsur yang sangat penting.

3) Variability

Jasa bersifat sangat variabel karena merupakan nonstandardizet output, artinya banyak bervariasi bentuk, kualitas dan jenis, tergantung pada siapa, kapan, dan dimana jasa tersebut dihasilkan. Ada tiga faktor yang menyebabkan variabilitas kualitas jasa, yaitu kerjasama atau partisipasi publik selama penyampaian jasa, moral/motivasi pegawai dalam melayani publik dan beban kerja pemerintah.

4) Perishability

Jasa merupakan komoditas tidak tahan lama dan tidak dapat disimpan. Dengan demikian bila suatu jasa tidak digunakan, maka jasa tersebut akan berlalu begitu saja. Kondisi ini tidak akan menjadi masalah jika permintaannya konstan. Tetapi 
kenyataannya permintaan publik akan jasa umumnya sangat bervariasi dan dipengaruhi faktor musiman.

Jadi jasa merupakan suatu tindakan atau perbuatan yang bersifat intangible yang ditawarkan ke pihak lain.

\section{Kualitas}

Menurut Goesh dan Davis dalam Tjiptono (2004) kualitas merupakan suatu kondisi dinamis yang berhubungan dengan produk, jasa, manusia proses, dan lingkungan yang memenuhi atau melebihi harapan. Menurut Krajewski dalam (Sumadi,2001), kualitas dapat ditinjau dari sudut pandang pegawai dan publik. Ditinjau dari pandangan pegawai, kualitas adalah jasa yang diberikan sesuai dengan standar dan ketetapan yang dibuat oleh Pemerintah.Sedangkan dari sudut publik kualitas adalah nilai atau kecocokan yang diterima.Dalam dasa warsa terakhir ini arti kualitas memang lebih banyak dilihat dari sudut publik karena dalam pemerintahan yang menyadari bahwa kelangsungan pembangunan pemerintah tergantung pada publik. Oleh karena itu publik sebagai penerima jasa harus diberi kepuasan dalam pelayanan.

\section{Pelayanan}

Pelayanan dapat diartikan sebagai pemberian layanan (melayani) keperluan orang atau publik yang mempunyai kepentingan pada organisasi itu sesuai dengan aturan pokok dan tata cara yang telah ditetapkan.

Sebagai mana telah dikemukakan terdahulu bahwa pemerintahan pada hakekatnya adalah pelayanan kepada publik.Ia tidaklah diadakan untuk melayani dirinya sendiri tetapi untuk melayani publik serta menciptakan kondisi yang memungkinkan setiap anggota publik mengembangkan kemampuan dan kreativitasnya demi mencapai tujuan bersama (Rasyid, 1998). Karena birokrasi publik berkewajiban dan bertanggung jawab untuk memberikan layanan yang baik dan profesional.

Layanan merupakan kegiatan untuk mempertahankan publik lama, menarik publik baru dan meninggalkan kesan mendalam kepada pemerintah sehingga para masyarakat atau investor mau berbisnis lagi di pemerintah. Dalam hal sikap layanan pada publik mencakup : perhatian, rasa hormat, integritas, realibilitas, suka menolong, keramahtamahan, pengetahuan, profesionalisme, efesien dan ketersediaan.

\section{Kualitas Pelayanan}

Pengertian Kualitas Pelayanan

Kualitas Pelayanan merupakan tingkat keunggulan yang diharapkan dan pengendalian atas tingkat keunggulan tersebut untuk memenuhi harapan publik (Tjiptono, 2004).Bitner dalam Sulistyo (1999), mengemukakan bahwa kualitas pelayanan yang dirasakan merupakan hasil dari perbandingan kinerja yang diterima publik dari penyedia jasa.

Oliver dalam Sulistyo (1999), menujukkan bahwa kualitas pelayanan keseluruhan ditentukan oleh kesesuaian keinginan yang dihasilkan dari perbandingan keinginan dan kinerja yang dirasakan konsumen.

Berdasarkan ketiga pengertian diatas, dapat disimpulkan bahwa kualitas pelayanan adalah suatu keunggulan yang dirasakan seseorang terhadap suatu jasa yang 
diharapkan dari perbandingan antara keinginan dan kinerja yang dirasakan publik setelah mendapatkan jasa tersebut.

Ciri-ciri atau atribut yang dapat menentukan kualitas pelayanan adalah :

1. Ketepatan waktu pelayanan, yang meliputi waktu tunggu dan waktu proses.

2. Akurasi pelayanan, yang meliputi bebas dari kesalahan.

3. Kesopanan dan keramahan dalam memberikan pelayanan.

4. Kemudahan mendapatkan pelayanan, misalnya banyaknya pegawai yang melayani dan banyaknya fasilitas pendukung seperti komputer.

5. Kenyamanan dalam memperoleh pelayanan, berkaitan dengan lokasi, ruang tempat pelayanan, tempat parkir, ketersediaan informasi dan lain-lain.

6. Atribut pendukung pelayanan lainnya seperti ruang tunggu ber AC, kebersihan dan lain-lain.

Terdapat dua faktor yang mempengaruhi kualitas pelayanan, yaitu pelayanan yang diharapkan (expected service) dan pelayanan yang ditawarkan (perseived service) (Perasuraman,et dalam Tjiptono,2004). Apabila jasa yang diterima atau dirasakan (percieved service) sesuai dengan yang diharapkan, maka kualitas jasa dipersepsikan baik dan memuaskan.

Kualitas harus dimulai dari kebutuhan publik dan berakhir pada persepsi publik (Kotler, 1999). Hal ini berarti bahwa citra kualitas yang baik bukanlah berdasarkan pada sudut pandang atau persepsi pihak penyedia jasa, melainkan berdasarkan pada sudut pandang atau persepsi publik. Persepsi publik terhadap kualitas jasa merupakan penilaian menyeluruh atas keunggulan suatu jasa.

Kualitas pelayanan dapat dikelompokkan atas technical quality baik berupa search quality, experience quality dan credence quality. Selanjutnya functional quality atau kualitas cara penyampaian jasa dan ketiga adalah corporate image yaitu reputasi, citra umum dan daya tarik bagi lembaga pemerintah (Fornell, 1994).

Faktor - Faktor yang dapat mempengaruhi kualitas pelayanan publik :

1). Struktur organisasi.

Menurut Anderson (1972), struktur adalah susunan berupa kerangka yang memberikan bentuk dan wujud, dengan demikian akan terlihat prosedurnya. Dalam organisasi pemerintahan, prosedur merupakan sesuatu rangkaian tindakan yang ditetapkan lebih dahulu, yang harus dilalui untuk mengerjakan sesuatu tugas.

Dalam pengendalian pelayanan perlu prosedur yang runtut yaitu antara lain penentuan ukuran, identifikasi, pemeliharaan catatan untuk inspeksi dan peralatan uji, penilaian, penjaminan, dan perlindungan (Gaspersz,1994).

Oleh karena itu struktur organisasi yang demikian akan berpengaruh positif terhadap pencapaian kualitas pelayananan. Akan tetapi, apabila struktur organisasi tidak disusun dengan baik maka akan dapat menghambat kualitas pelayanan publik yang baik.

Berdasarkan uraian diatas menunjukkan bahwa struktur organisasi mempunyai peranan yang sangat penting dalam suatu organisasi, sehingga dengan demikian struktur organisasi juga sangat berpengaruh terhadap kualitas pelayanan.

2). Kemampuan aparat.

Aparatur pemerintah adalah kumpulan manusia yang mengabdi pada kepentingan negara dan pemerintahan dan berkedudukan sebagai pegawai negeri (Tayibnapsis, 1993). Dengan kata lain aparatur Negara adalah para pelaksana kegiatan dan proses penyelenggaraan pemerintahan negara baik yang bekerja di dalam tiga badan eksekutif, legislatif, dan 
yudikatif maupun mereka sebagai TNI dan pegawai negeri sipil pusat dan daerah yang ditetapkan dengan peraturan-peraturan pemerintah.

Dari aparat negara dan aparatur pemerintah, diharapkan atau dituntut adanya kemampuan baik berupa pengetahuan, keterampilan serta sikap perilaku yang memadai, sesuai dengan tuntutan pelayanan dan pembangunan sekarang ini (Handayaningrat, 1986).

Berkaitan dengan hal kualitas pelayanan publik, maka kemampuan aparat sangat berperan penting dalam hal ini ikut menentukan kualitas pelayanan publik tersebut.

3). Sistem pelayanan.

Untuk sistem pelayanan perlu diperhatikan apakah ada pedoman pelayanan, syarat pelayanan yang jelas, batas waktu, biaya atau tarif, prosedur, buku panduan, media informasi terpadu, saling menghargai dari masing-masing unit terkait dengan publik yang membutuhkan pelayanan itu sendiri.

Dengan demikian sistem pelayanan adalah kesatuan yang utuh dari suatu rangkaian pelayanan yang sangat terkait, bagian atau anak cabang dari suatu sistem pelayanan terganggu maka akan mengganggu pula keseluruhan pelayanan itu sendiri. Dalam hal ini apabila salah satu unsur pelayanan yang kualitasnya rendah atau lamanya waktu pengurusan maka akan merusak citra pelayanan di suatu tempat.

Dimensi-Dimensi Kualitas Pelayanan

Menurut Pasuraman,dkk dalam Sumadi (2001) faktor utama yang menentukan kualitas layanan yaitu :

1. Tangible (bukti fisik) dari jasa, bisa berupa fasilitas fisik, peralatan dan sarana komunikasi yang digunakan pegawai.

2. Empathy (perhatian) meliputi kemudahan dalam melakukan hubungan, komunikasi, yang baik, perhatian pribadi dan memahami kebutuhan publik.

3. Reliability (keandalan) yaitu untuk mengukur kemampuan dalam memberikan jasa yang tepat dan dapat diandalkan.

4. Responsiveness (daya tanggap) merupakan keinginan untuk membantu para pelanggan dan memberikan pelayanan dengan tanggap.

5. Assurance (jaminan) mencakup pengetahuan, kemampuan, kesopanan dan keragu - raguan.

Prinsip-prinsip Kualitas Pelayanan

Untuk menciptakan suatu lingkungan yang kondusif dalam memperbaiki kualitas, maka lembaga harus mampu memenuhi enam prinsip utama.Keenam prinsip tersebut sangat bermanfaat dalam membentuk dan mempertahankan lingkungan yang tepat untuk melaksanakan penyempurnaan kualitas secara kesinambungan dengan didukung oleh pegawai dan publik.

Enam prinsip pokok tersebut meliputi (Tjiptono; 2004) :

1). Kepemimpinan

Starategi kualitas instansi harus merupakan inisiatif dan komitmen Atasan.Atasan harus memimpin kantornya untuk meningkatkan kualitas kinerjanya. Tanpa adanya atasan dari kantor tersebut, maka usaha untuk meningkatkan kualitas kerja hanya berdampak kecil terhadap kantor tersebut.

2). Pendidikan

Semua pihak kantor dari atasan sampai dengan staf operasional harus memperoleh pendidikan mengenai kualitas. Aspek-aspek yang perlu mendapat penekanan 
dalam pendidikan tersebut meliputi konsep kualitas sebagai strategi bisnis, alat dan teknik implementasi strategi kualitas dan peranan eksekutif dalam implementasi strategi kualitas.

3). Perencanaan

Proses perencanan strategik harus mencakup pengukuran dan tujuan kualitas yang dipergunakan

dalam mengarahkan kantor untuk mencapai visinya.

4). Review

Proses review merupakan satu-satunya alat yang paling efektif bagi atasan untuk mengubah perilaku organisasional. Proses ini merupakan suatu mekanisme yang menjamin adanya perhatian yang konstan untuk mencapai tujuan kualitas.

5). Komunikasi

Implementasi strategi kualitas dalam organisasi dipengaruhi oleh proses komunikasi dalam kantor. Komunikasi harus dilakukan dengan pegawai, publik, dan yang lainnya.

6). Penghargaan dan Pengakuan

Penghargaan dan pengakuan merupakan aspek yang paling penting dalam implementasi strategi kualitas. Setiap pegawai yang berprestasi baik perlu diberi penghargaan dan prestasinya tersebut diakui. Dengan demikian dapat meningkatkan motivasi, moral kerja, rasa bangga, dan rasa kepemilikan setiap organisasi, yang pada gilirannya dapat memberikan kontribusi besar bagi kantor dan bagi publik yang dilayani.

\section{Faktor-faktor Kualitas Pelayanan}

Faktor-faktor yang mempengaruhi kualitas pelayanan pada birokrasi pemerintah. Untuk pelayanan birokrasi pemerintah ada beberapa faktor yang mempengaruhi yaitu :

1) Faktor internal kewenangan kepala, sikap yang berorientasi terhadap perubahan, budaya organisasi, etika organisasi, semangat kerja sama. Faktor eksternal meliputi budaya politik, dinamika dan perkembangan politik, kontrol publik .

2) Profesionalisme lapangan kerja tertentu yang diduduki oleh orang-orang yang memiliki kemampuan tertentu pula.

3) Kepemimpinan seorang pimpinan yang mempunyai visi tentu akan mampu mengelola organisasi dan segala sumber daya yang mendukung.

4) Kewenangan atasan secara konseptual merupakan langkah yang ditempuh oleh administrator untuk menyelesaikan kasus tertentu yang tidak atau belum diatur dalam regulasi baru. Tujuan dari tindakan atasan adalah agar mekanisme dan proses kerja yang ada tidak mengalami kemacetan.

Apabila faktor - faktor yang mempengaruhi kualitas pelayanan sudah dimiliki oleh suatu organisasi maka pelayanan pada publik akan lebih cepat dan bisa memenuhi harapan publik.

Bagi organisasi pemerintah apabila faktor di atas dipenuhi maka mampu meningkatkan pendapatan daerah, karena peningkatan kualitas pelayanan secara otomatis akan meningkatkan kepercayaan publik pada layanan pemerintah.

\section{Kepuasan Publik}


Kepuasan publik adalah perasaan senang atau kecewa yang muncul setelah membandingkan antara proyeksi dan kenyataan terhadap kinerja (hasil) suatu produk sesuai dengan harapan dan keinginan mereka (Kotler, 2002).

Kunci utama untuk memenangkan persaingan adalah memberikan nilai dan kepuasan

publik melalui penyampaian jasa berkualitas dengan biaya yang jelas.

Sistem Kepuasan Publik

Menurut Gaspersz (2002), menyatakan pendekatan yang digunakan dalam sistem kepuasan publik adalah :

1) Komitmen manajemen puncak, pelayanan publik dan peningkatan mutu akan berhasil apabila ada komitmen menyeluruh dan dimulai dari puncak.

2) Kenali publik secara dekat dan menyeluruh.

3) Mengembangkan standar kinerja pelayanan publik dan mutu pelayanan publik, yang merupakan benda tidak berwujud dan dasarnya adalah persepsi walaupun demikian mereka memiliki aspek berwujud dan nyata dan bisa diukur.

4) Angkat, latih dan beri imbalan staf yang baik karena ikatan publik hanya bias diberi oleh orang yang berkompeten dan berkualifikasi.

5) Berikan imbalan pada prestasi mutu pelayanan, baik terhadap karyawan maupun publik dengan memberikan insentif psikologis dan juga financial terhadap orang - orang di lingkungan lembaga pemerintah.

6) Tetaplah dekat dengan publik.

7) Menciptakan perbaikan berkesinambungan karena tidak ada system yang sempurna maka dari itu harus terus menerus bekerja untuk memperbaiki mutu pelayanan dan kinerja.

Manfaat Kepuasan Publik

Pada prinsipnya, kualitas jasa berpotensi menciptakan kepuasan publik yang pada giliraannya akan memberikan sejumlah manfaat seperti (Tjiptono, 2004) :

a. Terjalin relasi saling menguntungkan jangka panjang antar pemerintah dan para publik.

b. Terbukanya peluang pertumbuhan melalui pengurusan ulang, dan untuk selanjutnya.

c. Loyalitas publik dapat terbentuk.

d. Terjadinya komunikasi mulut ke mulut yang bersifat positif yang berpotensi menarik publik baru.

e. Persepsi publik terhadap reputasi pemerintah semakin positif.

f. Jumlah pengurusan izin diperoleh bisa meningkat.

\section{Pengukuran Tingkat Kepuasan Publik}

Alasan utama dalam pengukuran tingkat kepuasan publik (Barnes, 2003) adalah :

1) Mempelajari persepsi publik, karena publik memiliki sifat individual dan setiap orang akan memandang sesuatu secara berbeda dengan orang lain.

2) Tentukan kebutuhan, keinginan, persyaratan, dan harapan publik.

3) Menutup kesenjangan, karena antara penyedia dan publik memiliki perbedaan persepsi. 
4) Memeriksa peningkatan mutu kepuasan publik apakah sesuai atau tidak.

5) Menetapkan tujuan bisnis berdasarkan persyaratan dan harapan publik dan kemudian mengukur kinerja dengan tujuan yang telah ditetapkan.

6) Meningkatkan kinerja mutu pelayanan dan penyampaian

7) diharapkan akan mendapatkan peningkatan laba.

8) Pelajari bagaimana melakukannya dan apa yang harus dilakukan dengan melakukan penilitian pelanggan maka dari itu publik akan memberitahukan strategi atau arah bisnis apa yang perlu diubah.

9) Terapkan proses perbaikan berkesinambungan yang apabila tidak maka pesaing yang akan melakukan.

\section{Kegunaan Survei Publik}

Kegunaan survei kepuasan publik adalah untuk memperbaiki dan meningkatkan kinerja atau jasa lembaga pemerintahan. Data survei akan dapat mendorong lembaga pemerintah memahami perilaku publik, sehingga dapat dijadikan bahan untuk menyusun strategi manajemen pemerintah. Jadi apabila survei kepuasan publik digunakan maka ini akan dapat menjadi alat pengambilan keputusan.

\section{Hubungan Antara Kualitas Pelayanan dan Kepuasan Publik}

Salah satu faktor yang dominan berpengaruh pada kepuasan publik adalah kualitas layanan.Tingkat kualitas layanan sangat menentukan kepada kepuasan publik. Dengan kata lain semakin baik kualitas pelayanan yang diberikan maka akan semakin tinggi tingkat kepuasan yang dirasakan publik tersebut.

\section{Hipotesis Penelitian}

1. Tangible berpengaruh signifikan terhadap kepuasan publik dalam pengurusan perizinan pada Badan Pelayanan Perizinan Terpadu, Pengadaan Barang dan Jasa (BP2TPBJ).

2. Empathy berpengaruh signifikan terhadap kepuasan publik dalam pengurusan perizinan pada Badan Pelayanan Perizinan Terpadu, Pengadaan Barang dan Jasa (BP2TPBJ).

3. Reliability berpengaruh signifikan terhadap kepuasan publik dalam pengurusan perizinan pada Badan Pelayanan Perizinan Terpadu, Pengadaan Barang dan Jasa (BP2TPBJ).

4. Responsiveness berpengaruh signifikan terhadap kepuasan publik dalam pengurusan perizinan pada Badan Pelayanan Perizinan Terpadu, Pengadaan Barang dan Jasa (BP2TPBJ).

5. Assurance berpengaruh signifikan terhadap kepuasan publik dalam pengurusan perizinan pada Badan Pelayanan Perizinan Terpadu, Pengadaan Barang dan Jasa (BP2TPBJ).

\section{METODE PENELITIAN \\ Objek Penelitian}

Adapun yang menjadi objek dalam penelitian ini adalah persepsi publik Kabupaten Dharmasraya yang mendapatkan jasa pelayanan publik dalam pengurusan perizinan yaitu Surat Izin Tempat Usaha (SITU) di Badan Pelayanan Terpadu, Pengadaan Barang dan Jasa. 


\section{Populasi dan sampel}

Populasi merupakan sekumpulan orang, peristiwa atau sesuatu yang menarik perhatian peneliti untuk diteliti (Sekaran,2003), sedangkan menurut Sugiono (2002), populasi adalah wilayah generalisasi yang terdiri dari objek atau subjek yang menjadi kuantitas dan karakteristik tertentu yang ditetapkan oleh peneliti untuk dipelajari dan kemudian ditarik kesimpulannya.

Populasi sasaran adalah populasi spesifik yang relevan dengan tujuan penelitian atau masalah penelitian .Dengan demikian yang menjadi sasaran populasi dalam penelitian ini adalah keseluruhan publik Kabupaten Dharmasraya yang pernah mendapatkan jasa pelayanan pengurusan izin SITU.

Menurut Sekaran (2003), sampel merupakan bagian dari populasi. Sejalan dengan penelitian ini, maka pengambilan sampel dilakukan dengan menggunakan persampelan non-probabilitas. Alasan menggunakan sampel non probabilitas ini adalah tidak tersedianya data base jumlah populasi penelitian. Menurut (Kuncoro,2003) yang dimaksud dengan populasi dalam penelitian ini adalah jumlah pelanggan pada Badan Pelayanan Perizinan Terpadu, Pengadaan Barang dan Jasa yang mendapat pelayanan jasa pembuatan izin SITU.

Dalam penyebaran kuesioner atau sampel non probabilitas, penelitian ini menggunakan sampel berdasarkan kebetulan saja (accidental sampling) yaitu para pelanggan yang datang ke kantor Badan Pelayanan Perizinan Terpadu, Pengadaan Barang dan Jasa yang secara kebetulan bertemu dengan peneliti dan dapat digunakan sebagai sampel dan layak sebagai sumber data (Rochaety, Trasnati, dan Latief, 2007)

\section{Metode Pengumpulan Data}

Didalam pengumpulan data dan informasi yang diperlukan dalam penulisan ini, adalah dengan melakukan :

a. Kuesioner (angket)

Kuesioner adalah sejumlah pertanyaan tertulis yang digunakan untuk memperoleh informasi dari responden dalam arti laporan tentang pribadinya, atau hal-hal yang ia ketahuinya (Arikunto, 1997)

Dalam pengumpulan data untuk mendukung penelitian ini, peneliti menyebarkan kuisioner penelitian secara langsung (drop dan pick) kepada masyarakat yang pernah mengurus izin / SITU di Badan Pelayanan Perizinan Terpadu, pengadaan Barang dan Jasa (BP2TPBJ). Penyebaran kuisioner tersebut dilakukan selama 5 (lima) hari kerja yaitu mulai tanggal 7 s.d.11 September 2009. Responden diminta untuk membaca dan mengisi altenatif jawaban yang telah disediakan sehubungan dengan persepsi / penilaian mereka terhadap kualitas pelayanan dan tingkat kepuasan mereka.

b. Studi Kepustakaan (Library Research)

Yaitu pengumpulan data bersifat teoritis yang diperoleh dari literatur-literatur serta bacaan yang erat kaitannya dengan masalah yang diteliti.

\section{Teknik Analisa Data}

Untuk menganalisis data dan pengujian hipotesis, penelitian ini akan menggunakan beberapa teknik analisis statistik melalui pemanfaatan Statistical Package for Social Science (SPSS) versi 16.0 for Windows antara lain adalah : 


\section{Statistik Deskriptif}

Statistik deskriptif adalah statistik yang digunakan untuk menggambarkan atau mendeskripsikan data yang telah dikumpulkan menjadi sebuah informasi (Kuncoro, 2003).Analisis statistik deskriptif digunakan untuk mendeskripsikan profil responden, nilai rata-rata variabel kualitas pelayanan dan kepuasan publik serta distribusi frekuensi jawaban responden terhadap masing - masing pertanyaan pada masing masing variabel.

\section{Analisa Reliabilitas}

Reliabilitas digunakan untuk melihat sejauhmana suatu instrumen yang digunakan beberapa kali untuk megukur objek yang sama, akan menghasilkan data yang sama (Sugiyono,2004). Untuk mengetahui reliabilitas variabel Tangible (XI), Empathy (X2), Reliability (X3), Responsiveness (X4), Assurance (X5) dan kepuasan publik (Y), digunakan Cronbach's alpha minimal 0.70 (Sekaran, 2003).

Analisa Validitas

Suatu skala pengukuran disebut valid bila ia melakukan apa yang seharusnya dilakukan dan mengukur apa yang seharusnya diukur (Kuncoro, 2003 ; Sekaran, 2003). Untuk mengetahui apakah pertanyaan - pertanyaan valid atau tidak, maka digunakan bivariate correlation yaitu mengkorelasikan masing - masing item pertanyaan berkorelasi signifikan dengan total item pertanyaan maka item tersebut dinyatakan valid dan sebaliknya.

\section{Analisa Korelasi}

Analisis korelasi adalah suatu teknik stastistik yang digunakan untuk mengukur hubungan antara dua variabel (Widyono, 1999). Dalam penelitian ini, hubungan antara variabel kepuasan publik dan dimensi kualitas pelayanan (Tangible, Empaty, Reliability, Responsiveness , Assurance = TERRA) dideteksi melalui korelasi bevariate (bivariate correlation) dengan menggunakan Person's Correlation.

Analisis Regresi Linear Berganda

Analisis regresi berganda adalah suatu teknik statistik yang digunakan untuk mengetahui seberapa besar pengaruh beberapa variabel bebas terhadap variabel terikat (Kuncoro, 2003).Oleh karena itu, tujuan menggunakan analisa regresi linear berganda dalam penelitian ini adalah untuk mengetahui seberapa besar pengaruh variabel dimensi kualitas pelayanan (TERRA) secara simultan terhadap kepuasan publik.

Dengan demikian, dapat dikemukakan persamaan regresi linear berganda dalam penelitian ini adalah sebagai berikut :

$Y=a+b_{1} X_{1}+b_{2} X_{2}+b_{3} X_{3}+b_{4} X_{4}+b_{5} X_{5}$

Dimana,

Y : Kepuasan publik

a : Konstanta

b 1,2,3,4,5: Koefisien regresi

$\mathrm{X} 1 \quad$ : Tangibles

X2 : Empathy

X3 : Reliability

X4 : Responsiveness

X5 : Assurance 


\section{HASIL DAN PEMBAHASAN \\ Keadaan Geografis Kabupaten Dharmasraya}

Kabupaten Dharmasraya berdiri sejak tanggal 7 Januari 2004 dan merupakan salah satu dari tiga Kabupaten yang baru dibentuk di Propinsi Sumatera Barat pada akhir Tahun 2003, berdasarkan Undang-Undang Nomor 38 Tahun 2003 tentang Pembentukan Kabupaten Dharmasraya, Kabupaten Solok Selatan dan Kabupaten Pasaman Barat di Propinsi Sumatera Barat (Lembaran Negara Nomor 153, Tambahan Lembaran Negara Republik Indonesia Nomor 4348).

Kabupaten Dharmasraya merupakan salah satu Kabupaten yang cukup potensi di Propinsi Sumatera Barat.Dengan luas wilayah yang mencapai 2.964,13 Km atau 296,413 Ha. Kabupaten ini lahir dari Pemekaran Kabupaten Sawahlunto Sijunjung dan terdiri dari 11 Kecamatan yaitu Pulau Punjung, Sitiung, Koto Baru, Sungai Rumbai, IX Koto, Koto Salak, Padang Laweh, Asam JUjuhan, Koto Besar, Timpeh, dan Tiumang.

Kabupaten Dharmasraya berada pada posisi Geografis $0^{0} 47^{\prime} 7$ ' LS - $1^{0} 41^{\prime}$ '56" LS dan $101^{0}$ 9' 21' 'BT - $101^{0}$ 54' 27' BT.

Kabupaten Dharmasraya berbatasan langsung dengan Kabupaten yaitu :

a. Sebelah Utara berbatasan dengan Kabupaten Sijunjung.

b. Sebelah Selatan berbatasan dengan Kabupaten Tebo Propinsi Jambi.

c. Sebelah Timur berbatasan dengan Kabupaten Kuantan Singingi Propinsi Riau.

d. Sebelah Barat dengan Kabupaten Solok dan Solok Selatan.

Kondisi topografi Kabupaten Dharmasraya mayoritas merupakan lahan datar dengan ketinggian dari 100 meter sampai 500 meter dari permukaan laut. Selama tahun2005 rata-rata curah hujan mencapai 12.83 hari/bulan di Kecamatan Sungai Rumbai, 12,92 hari/bulan di Kecamatan Koto Baru,13,17 hari/bulan di Kecamatan Sitiung dan 12,71 hari/bulan di Kecamatan Pulau Punjung.

Komposisi lahan Kabupaten Dharmasraya terbanyak adalah hutan perkebunan. Pada Tahun 2005 luas hutan tercatat $133.186 \mathrm{Ha}$ atau 44.98\%. sementara perkebunan seluas $118.803 \mathrm{Ha}$ atau $40.12 \%$ dan untuk pemukiman penduduk baru seluas 6.060 Ha atau $2.05 \%$.

\section{Pemerintahan Kabupaten Dharmasraya}

Dharmasraya pada tahun kedua pasca pemekaran ditandai dengan kegiatan pembangunan mulai dari tingkat Nagari bahkan Jorong.Di Kabupaten Dharmasraya terdapat sebanyak 52 Nagari yang tersebar di sebelas Kecamatan.

Dengan terbentuknya Nagari selanjutnya pembangunan yang dilaksanakan di Kabupaten Dharmasraya tentu akan berbasis Nagari. Jika ditunjang dengan semangat membangun dari tingkat Nagari maka aspirasi publik akan mudah disalurkan melalui Nagari.

Cakupan wilayah Nagari menjadi lebih luas dibandingkan dengan Desa, berdasarkan data terakhir Nagari Koto Besar di Kecamatan Sungai Rumbai merupakan Nagari terluas di Kabupaten Dharmasraya dengan luas wilayah mencapai 431,60 KM². Sedangkan Nagari Sungai Rumbai merupakan Nagari terkecil cakupan wilayahnya di Kabupaten Dharmasraya yang hanya $8,71 \mathrm{KM}^{2}$. 
Selanjutnya, jika dilihat dari jumlah penduduk pada akhir tahun 2005 Nagari Sitiung merupakan Nagari terbanyak jumlah penduduknya yaitu sebanyak 17.459 jiwa.Sedangkan Nagari yang paling sedikit penduduknya adalah Nagari Lubuk Karak di Kecamatan Pulau Punjung dimana penduduknya berjumlah 3.301 jiwa.

Dari sisi pemerintahan, Kabupaten Dharmasraya yang baru dibentuk pada Tahun 2004 saat ini dipimpin oleh Bapak H. Marlon Martua dan Bapak Tugimin sebagai Bupati dan Wakil Bupati Dharmasraya dengan masa jabatannya tahun 2005-2010. Sedangkan DPRD Kabupaten Dharmasraya dipimpin oleh Bapak Ir. Adi Gunawan, MM dengan periode 2009 - 2014.

Secara perlahan jumlah pegawai yang tercatat di Pemerintah Kabupaten Dharmasraya pada Tahun 2006 mengalami peningkatan dibanding jumlah pegawai pada tahun sebelumnya. Sampai dengan akhir Tahun 2006 jumlah pegawai yang tercatat di Lingkungan Pemerintah Kabupaten Dharmasraya adalah sebanyak 2.423 orang yang tersebar di seluruh Satuan Kerja Perangkat Daerah (SKPD).

Jika dilihat menurut Gender dari jumlah 2.423 orang tercatat sebanyak 1.287 orang atau sekitar 53.1\%.dalam hal ini peranan wanita dalam aktivitas di Birokrasi Pemerintahan sedikit lebih banyak dari kaum lelaki. Sedangkan jika dilihat dari golongan gaji, dari 2.423 orang tercatat sebanyak 92 orang orang golongan I, 657 orang golongan II, 1.537 orang golongan III dan 137 orang golongan IV.

Keanggotaan DPRD Kabupaten Dharmasraya periode 2009 - 2014 berjumlah 25 orang, dimana semuanya berasal dari partai politik pemenang Pemilu, sebab mulai dari periode 2004 - 2009 tidak ada lagi utusan TNI/POLRI. Dilihat dari sisi pendidikan yang ditamatkan, 32\% anggota DPRD Kabupaten Dharmasraya memiliki Ijazah Sarjana dan berbagai tingkatan dan $68 \%$ anggota DPRD tamat SLTA.

\section{Badan Pelayanan Perizinan Terpadu, Pengadaan Barang dan Jasa}

Badan Pelayanan Perizinan Terpadu, Pengadaan Barang dan Jasa (BP2TPBJ) dibentuk berdasarkan Peraturan Daerah Kabupaten Dharmasraya Nomor 7 Tahun 2008 Tentang Pembentukan Stuktur Organisasi dan Tata Kerja Lembaga Teknis Daerah Kabupaten Dharmasraya.

Badan Pelayanan Perizinan Terpadu, Pengadaan Barang dan Jasa memberikan pelayanan secara terpadu pada satu tempat oleh beberapa Satuan Kerja Perangkat Daerah (SKPD) di lingkungan Kabupaten Dharmasraya sesuai kewenangannya dan dioperasikan secara resmi oleh Bupati Dharmasraya pada tanggal 10 Desember 2007.

Badan Pelayanan Perizinan Terpadu, Pengadaan Barang dan Jasa sebagai Perangkat Daerah Penyelenggara Pelayanan Terpadu Satu Pintu, selanjutnya disingkat BP2TPBJ adalah perangkat daerah yang memiliki tugas pokok dan fungsi mengelola semua bentuk pelayanan perizinan dan pengadaan barang/jasa dengan sistem satu pintu.

PenyelenggaraanPelayanan Terpadu Satu Pintu adalah kegiatan penyelenggaraan perizinan yang proses pengelolaannya mulai dari tahap terbitnya dokumen dilakukan dalam satu tempat.Tujuan Penyelenggaraan Pelayanan Terpadu Satu Pintu adalah meningkatkan kualitas layanan publik dan memberikan akses yang lebih luas kepada publik untuk memperoleh pelayaan publik. Sasaran Penyelenggaraan Pelayanan terpadu satu Pintu adalah terwujudnya pelayanan publik yang cepat, murah, mudah, transparan, pasti dan terjangkau dan meningkatkan hak-hak publik terhadap pelayanan publik. 
Badan Pelayanan Perizinan Terpadu, Pengadaan Barang dan Jasa terdiri dari 4 bidang yaitu Bidang Perizinan yang bertugas melaksanakan proses administrasi dan penertiban surat izin serta penerimaan retribusi perizinan. Bidang Penertiban dan pengaduan yaitu bertugas menginventarisir seluruh jenis perusahaan yang ada di Kabupaten Dharmasraya, baik yang memiliki izin maupun tidak dan administrasi dan inventarisir jenis-jenis pengaduan publik. Bidang Evaluasi dan pengendalian bertugas melaksanakan koordinasi dengan pihak-pihak terkait secara terpadu, berkala dan kontiniu dalam rangka pengawasan dan pengendalian perizinan dan melaksanakan penyebarluasan informasi mengenai perizinan kepada seluruh elemen publik baik informasi satu arah maupun dua arah. Sedangkan Bidang Pengadaan Barang dan Jasa bertugas dalam proses pemilihan penyedia barang dan jasa secara terpadu.

\section{Visi dan Misi Badan Pelayanan Perizinan Terpadu, Pengadaan Barang dan Jasa Kabupaten Dharmasraya}

Visi: "Terdepan Dan Prima Dalam Pelayanan Perizinan Dan Pengadaan Barang Dan Jasa"

Misi

1) Mewujudkan mekanisme pelayanan perizinan dan pengadaan barang dan jasa berbasis sistem informasi.

2) Menciptakan pelayanan perizinan dan pengadaan barang dan jasa yang prima melalui peningkatan kualitas SDM aparatur yang profesional dan system kinerja yang proporsional.

\section{Struktur Organisasi Badan Pelayanan Perizinan Terpadu, Pengadaan Barang dan Jasa Kabupaten Dharmasraya.}

Struktur Organisasi Badan Pelayanan terpadu Pengadaan barang dan Jasa (BP2TPBJ) ditetapkan dengan Peraturan Daerah Kabupaten Dharmasraya Nomor 07 Tahun 2008 tentang Pembentukan Stuktur Organisasi dan Tata Kerja Lembaga Teknis Daerah.

Struktur Organisasi Badan Pelayanan Perizinan Terpadu, Pengadaan Barang dan Jasa sebagai berikut (Lampiran IV) :

1. Kepala Badan

2. Sekretaris

3. Bidang :

a. Bidang Perizinan

b. Bidang Penertiban dan Pengaduan

c. Bidang evaluasi dan pengendalian

d. Bidang pengadaan Barang dan jasa

4. Sub Bidang

a. Sub Bagian Umum/Kepegawaian

b. Sub Bagian Keuangan

c. Sub Bagian Perencanaan Program

Badan Pelayanan Perizinan Terpadu, Pengadaan Barang dan Jasa mempunyai tugas membantu kepala daerah dalam melaksanakan koordinasi dan penyelenggaraan pelayanan administrasi di bidang perizinan dan pengadaan batang dan jasa secara terpadu dengan prinsip koordinasi, integrasi, sinkronisasi, simplikasi, keamanan, dan kepastian berdasarkan kebijakan yang ditetapkan oleh Kepala Daerah. Untuk 
menyelenggarakan tugas pokok tersebut Badan Pelayanan Perizinan Terpadu, Pengadaan Barang dan Jasa mempunyai fungsi :

a. Pelaksanaan penyusunan program Badan Pelayanan Perizinan Terpadu, Pengadaan Barang dan Jasa (BP2TPBJ);

b. Penyelenggaraan pelayanan administrasi pelayanan perizinan;

c. Pelaksanaan koordinasi proses pelayanan perizinan;

d. Pelaksanaan adminisrtrasi pelayanan perizinan;

e. Pemantauan dan evaluasi proses pemberian pelayanan perizinan;

f. Pelaksanaan proses-proses kegiatan pengadaan barang dan jasa;

g. Pelaksanaan tugas-tugas lain yang diberikan oleh Bupati sesuai dengan tugas dan fungsinya.

\section{Mekanisme Kerja Badan Pelayanan Perizinan Terpadu, Pengadaan Barang dan Jasa}

Mekanisme pelayanan dirancang dengan menerapkan pola koordinasi dalam pemberian pelayanan perizinan. Pola koordinasi dibayangkan sebagai dua sisi mata uang yang memberikan ruang terhadap BP2TPBJ sebagai pengelola administrasi perizinan masing-masing SKPD sebagai unsur yang merekomendasikan perizinan serta pengawasan untuk ikut andil dalam proses penyelesaian permohonan izin.

\section{Jenis-Jenis Perizinan Daerah}

Sampai dengan saat ini Badan Pelayanan Perizinan Terpadu, Pengadaan Barang dan Jasa Kabupaten Dharmasraya baru menangani 10 jenis perizinan dari 61 izin yang dikeluarkan Pemerintah Kabupaten Dharmasraya. Izin-izin yang kewenangannya telah diserahkan ke Badan Pelayanan Perizinan Terpadu, Pengadaan Barang dan Jasa Kabupaten Dharmasraya adalah :

1. Izin Lokasi

2. Surat Izin Tempat Usaha

3. Hinder Ordinate ( SITU HO)

4. Izin Mendirikan Bangunan (IMB)

5. Surat Izin Usaha Perdagangan (SIUP)

6. Tanda Taftar Perusahaan (TDP)

7. Tanda Daftar Industri (TDI) dan Izin Usaha Industri (IUI)

8. Tanda Daftar Gudang

9. Surat Izin Usaha Jasa Kontruksi (SIUJK)

10. Izin Reklame

\section{Pembahasan}

Penelitian ini menggunakan teknik pengumpulan sampel dengan menyebarkan kuesioner kepada masyarakat yang mengurus izin SITU. Kuesioner yang disebarkan sebanyak 60 orang. Proses penyebaran kuesioner mulai dilakukan selama 5 hari dari tanggal 7 September s/d 11 September 2009.

\section{Uji Validitas}

Setelah melakukan pengolahan data dengan SPSS for windows versi 16.0 maka diperoleh hasil uji validitas, untuk menunjukan tingkat validnya data yang diperoleh. Menurut Pearson Momen (2006 : 108), bila koefisien 
korelasi (r) sama dengan 0,3 atau lebih maka butir item variabel dinyatakan valid, dari data yang diperoleh berdasarkan jawaban resoponden maka dapat dilihat untuk variabel tangible (X1) nilai validitasnya sebagai berikut :

Tabel 4.4.

Hasil Uji Validitas

Variabel Tangible (X1)

\begin{tabular}{|l|c|l|}
\hline m variabel & fisien Korelasi & \multicolumn{1}{|c|}{ Validitas } \\
\hline $1_{1}$ & 0,467 & Valid \\
\hline $1_{2}$ & 0,710 & Valid \\
\hline $1_{3}$ & 0,787 & Valid \\
\hline $1_{4}$ & 0,601 & Valid \\
\hline
\end{tabular}

Sumber : pengolahan data (lampiran VIII)

Dari data yang diperoleh berdasarkan jawaban responden pada variabel (Tangible) semua item variabelnya valid, karena hasil koofisien korelasi lebih besar dari 0.3 , sehingga dari 4 butir item variabel dinyatakan valid sebagai alat ukur yaitu $\mathrm{X} 1_{1}(0,467), \mathrm{X}_{2}(0,710), \mathrm{X} 1_{3}(0,787), \mathrm{X} 1_{4}(0,601)$.

Berdasarkan tabel diatas dapat kita dilihat bahwa, item yang paling tinggi adalah (0.787) yaitu pegawai Badan Pelayanan Perizinan Terpadu, Pengadaan Barang dan Jasa harus berpenampilan rapi sehingga publik merasa senang dan puas dengan layanan yang diterima, diharapkan supaya di pertahankan dan melakukan perbaikan. Sedangkan item yang paling kecil adalah $(0,467)$ dimana pegawai Badan Pelayanan Terpadu, Pengadaan Barang dan Jasa tidak memiliki peralatan yang memadai, sehingga ini dapat memperlambat proses dalam pembuatan izin, diharapkan untuk lebih diperhatikan karena sangat berpengaruh terhadap kepuasan publik yang di berikan.

Tabel 4.5.

Hasil Uji Validitas

Variabel Empathy (X2)

\begin{tabular}{|c|c|c|}
\hline Butir item variabel & Koofisien Korelasi & Validitas \\
\hline $\mathrm{X} 2_{1}$ & 0,605 & Valid \\
\hline $\mathrm{X} 2_{2}$ & 0,759 & Valid \\
\hline $\mathrm{X} 2_{3}$ & 0.732 & Valid \\
\hline $\mathrm{X} 2_{4}$ & 0,793 & Valid \\
\hline
\end{tabular}




\section{Sumber : pengolahan data (lampiran I}

Dari data yang diperoleh berdasarkan jawaban responden pada variabel (Empathy) semua item variabelnya valid, karena hasil koofisien korelasi lebih besar dari 0.3. Jadi dari tabel diatas dapat disimpulkan terdapat 4 butir item variabel valid yaitu X2 $2_{1}(0,605), X 2_{2}(0,759), X 2_{3}(0,732), X 2_{4}(0,793)$

Berdasarkan tabel diatas, item yang paling tinggi adalah $(0,793)$ yaitu pegawai harus meluangkan waktunya untuk saling kenal dengan publik sehingga terjalin komunikasi yang baik dan lancar, sedangkan item yang paling kecil $(0,605)$ yaitu pegawai Badan Pelayanan Perizinan Terpadu,Pengadaan Barang dan Jasa kurang bersikap sopan terhadap publik. Maka ini harus diperhatikan karena sangat berpengaruh dalam kualitas pelayanan, semakin baik kualitas pelayanan maka semakin banyak pula publik dalam pengurusan perizinan.

Tabel 4.6.

Hasil Uji Validitas

Variabel Reliability (X3)

\begin{tabular}{|c|c|c|}
\hline Butir item variabel & Koofisien Korelasi & Validitas \\
\hline $\mathrm{X} 3_{1}$ & 0,605 & Valid \\
\hline $\mathrm{X} 3_{2}$ & 0,759 & Valid \\
\hline $\mathrm{X} 3_{3}$ & 0,732 & Valid \\
\hline $\mathrm{X} 3_{4}$ & 0,793 & Valid \\
\hline
\end{tabular}

Sumber : pengolahan data (lampiran $X)$

Dari data yang diperoleh berdasarkan jawaban responden pada variabel (Reliability) semua item variabelnya valid, karena hasil koofisien korelasi lebih besar dari 0.3 . Terdapat 4 butir item variabel valid yaitu $\mathrm{X} 3_{1}(0,605), \mathrm{X} 3_{2}(0,759), \mathrm{X} 3_{3}$ $(0,732), \mathrm{X}_{4}(0,793)$.

Berdasarkan tabel diatas, koofisien korelasi yang paling tinggi adalah $(0,793)$ yaitu pegawai yang telah mengikuti pelatihan dan mempunyai pengetahuan yang baik maka ini harus diterapkan dalam

menjalankan tugas yang baik sehingga dapat memberikan keputusan yang tepat pada publik menurut aturan yang berlaku. Sedangkan koofisien korelasi yang paling kecil adalah $(0,605)$ yaitu pada Badan Pelayanan Perizinan Terpadu, Pengadaan Barang dan Jasa tidak memberikan pelayanan sesuai dengan waktu yang telah ditetapkan atau dijanjikan kepada publik, diharapkan untuk dapat diperhatikan karena sangat berpengaruh terhadap kualitas pelayanan dan kepuasan publik dalam pengurusan izin.

Tabel 4.7.

Hasil Uji Validitas

Variabel Responsiveness (X4) 


\begin{tabular}{|c|c|c|}
\hline Butir item variabel & Koofisien Korelasi & Validitas \\
\hline $\mathrm{X} 4_{1}$ & 0,521 & Valid \\
\hline $\mathrm{X} 4_{2}$ & 0,707 & Valid \\
\hline $\mathrm{X} 4_{3}$ & 0,610 & Valid \\
\hline $\mathrm{X} 4_{4}$ & 0,636 & Valid \\
\hline
\end{tabular}

Sumber : pengolahan data (lampiran XI)

Dari data yang diperoleh berdasarkan jawaban responden pada variabel (Responsiveness) semua item variabelnya valid, karena hasil koofisien korelasi lebih besar dari 0.3 .

Terdapat 4 butir item variabel valid yaitu $\mathrm{X} 4_{1}(0,521), \mathrm{X} 4_{2}(0,707), \mathrm{X} 4_{3}(0,610), \mathrm{X} 4_{4}$ $(0,636)$.

Berdasarkan tabel diatas, item variabel yang paling tinggi $(0,707)$ yaitu pegawai selalu bersedia membantu publik apabila menemui masalah dalam pengurusan izin, sehingga publik merasa puas. Sedangkan item yang paling kecil $(0,521)$ yaitu kurangnya pegawai Badan Pelayanan Perizinan Terpadu, Pengadaan Barang dan Jasa memberikan pelayanan dengan sesegera mungkin sesuai dengan urutan penggunan jasa, diharapkan untuk diperhatikan karena kinerja pegawai sangat berpengaruh dalam kualitas pelayanan dan akan membuat publik merasa nyaman dalam menunggu urutannya.

Tabel 4.8.

Hasil Uji Validitas

Variabel Assurance (X5)

\begin{tabular}{|c|c|c|}
\hline Butir item variabel & Koofisien Korelasi & Validitas \\
\hline $\mathrm{X} 5_{1}$ & 0,569 & Valid \\
\hline $\mathrm{X} 5_{2}$ & 0,590 & Valid \\
\hline $\mathrm{X} 5_{3}$ & 0,592 & Valid \\
\hline $\mathrm{X} 5_{4}$ & 0,592 & Valid \\
\hline
\end{tabular}

Sumber : pengolahan data (lampiran XII)

Dari data yang diperoleh berdasarkan jawaban responden pada variabel (Assurance) semua item variabelnya valid, karena hasil koofisien korelasi lebih besar dari 0.3. Terdapat 4 butir item variabel valid yaitu $\mathrm{X} 5_{1}(0,569), \mathrm{X} 5_{2}(0,590), \mathrm{X} 5_{3}$ $(0,592), \mathrm{X5}_{4}(0,592)$.

Berdasarkan tabel diatas, item variabel yang paling tinggi adalah $(0,592)$ yaitu pegawai Badan Pelayanan Perizinan Terpadu, Pengadaan Barang dan Jasa dapat memberikan jaminan dalam mejawab pertanyaan yang diajukan publik, diharapkan kinerja dan pengawasan terhadap kegiatan pelayanan selalu ditingkatkan sehingga tidak terjadi kesalahan pada hasil 
kinerja. Sedangkan item yang paling kecil $(0,569)$ yaitu pegawai tidak bisa meyakinkan publik untuk mempercayainya, sehingga publik tidak mendapatkan kepuasan dari layanan tersebut.

Dari data yang diperoleh berdasarkan jawaban responden untuk variabel kepuasan publik dengan menghitung korelasi dari butir item terhadap nilai totalnya. Korelasi yang digunakan adalah korelasi Pearson Moment, Bila korelasinya lebih dari 0,3 maka dinyatakan valid. Dengan mengggunakan program SPSS for windows 16.0 maka dapat dilihat validitasnya sebagai berikut :

Tabel 4.9.

Hasil Uji Validitas Variabel Kepuasan Publik (Y)

\begin{tabular}{|c|c|c|}
\hline Butir Item Varibel & Koefisien Korelasi & Validitas \\
\hline Y1 & 0,676 & Valid \\
\hline Y2 & 0,674 & Valid \\
\hline Y3 & 0,492 & Valid \\
\hline Y4 & 0,446 & Valid \\
\hline Y5 & 0,374 & Valid \\
\hline
\end{tabular}

Sumber :Pengolahan data (lampiran XIII)

Dari tabel diatas dapat disimpulkan, ternyata pada variabel kepuasan publik semua butir item variabelnya dinyatakan valid karena hasil koefisien korelasi lebih besar dari

0,3, sehingga 5 pertanyaan dalam dimensi ini valid sebagai alat ukur.

\section{Uji Reliabilitas}

Tabel. 4.10

Hasil Uji Reliabilitas

\begin{tabular}{|l|c|c|}
\hline \multicolumn{1}{|c|}{ Item variabel } & Cronbach's Alpha & N of Items \\
\hline Tangible $\left(\mathrm{X}_{1}\right)$ & .808 & 4 \\
\hline Empathy $\left(\mathrm{X}_{2}\right)$ & .852 & 4 \\
\hline Reliability $\left(\mathrm{X}_{3}\right)$ & .852 & 4 \\
& .801 & 4 \\
\hline Responsiveness $\left(\mathrm{X}_{4}\right)$ & .778 & 4 \\
\hline Assurance $\left(\mathrm{X}_{5}\right)$ & & \\
\hline
\end{tabular}

Berdasarkan tabel diatas setelah dilakukan uji reliabilitas sehingga di dapatkan nilai alpa cronbach's alpha tangible (0,808), Empathy $(0,852)$, Reliability $(0,852)$, Responsiveness $(0,801)$ dan Assurance $(0,778)$ memberikan hasil bahwa alat ukur ini memenuhi syarat untuk tangible, empathy. reliability, responsiveness, assurance dan kepuasan publik. Jadi 25 item pertanyaan diatas dapat dipakai sebagai alat ukur dalam penelitian ini. 


\section{Uji Korelasi}

Analisis korelasi adalah suatu teknik stastistik yang digunakan untuk mengukur hubungan antara dua variabel (Widyono, 1999).

Berdasarkan hasil penelitian besarnya nilai korelasi $(\mathrm{R})$ adalah $(0,744)$ ini menunjukkan korelasi hubungannya yang culup kuat antara variabel kualitas pelayanan (tangible, empathy, reliability, responsiveness dan assurance) terhadap kepuasan publik (Y) karena nilai r nya mendekati 1.

\section{Analisa Regresi Linear Berganda}

Analisis regresi berganda adalah suatu teknik statistik yang digunakan untuk mengetahui seberapa besar

pengaruh beberapa variabel bebas terhadap variabel terikat (Kuncoro, 2003).

Tabel 4.11

Hasil Regression

Coefficients $^{\mathrm{a}}$

\begin{tabular}{|c|c|c|c|c|c|}
\hline \multirow{2}{*}{ Model } & \multicolumn{2}{|c|}{$\begin{array}{l}\text { Unstandardized } \\
\text { Coefficients }\end{array}$} & \multirow{2}{*}{$\begin{array}{c}\begin{array}{c}\text { Standardized } \\
\text { Coefficients }\end{array} \\
\text { Beta }\end{array}$} & \multirow{2}{*}{$\mathrm{T}$} & \multirow{2}{*}{ Sig. } \\
\hline & B & Std. Error & & & \\
\hline (Constant) & 9.314 & 3.378 & & 2.757 & .008 \\
\hline Tangible & .377 & .305 & .190 & 1.233 & .223 \\
\hline Emphaty & .441 & .295 & .224 & 1.497 & .140 \\
\hline Reliability & .056 & .257 & .032 & .220 & .827 \\
\hline Responsiveness & .555 & .228 & .281 & 2.439 & .018 \\
\hline Assurance & .576 & .222 & .293 & 2.595 & .012 \\
\hline
\end{tabular}

Sumber : pengolahan data (lampiran XIV)

Dengan demikian, dapat dikemukakan persamaan regresi linear berganda dalam penelitian ini adalah sebagai berikut :

$$
Y=9.314+0.377 X_{1}+0.441 X_{2}+0.056 X_{3}+0.555 X_{4}+0.567 X_{5}
$$

Untuk mengetahui apakah apakah variabel bebas secara parsial berpengaruh signifikan terhadap variabel terikat dilakukan uji t. Pada tabel 4.15 diatas, maka terlihatlah nilai $\mathrm{t}$ hitung dari kualitas jasa (tangible, emphaty, reliability, 
responsiveness, assurance) berpengaruh terhadap kepuasan publik. Sedangkan nilai signifikan $(<0,05)$ berarti variabel bebas berpengaruh signifikan terhadap variabel terikat, dari hasil penelitian diatas bahwa variabel (tangible, emphaty, reliability) tidak signifikan terhadap kepuasan publik (tingkat probabilitas $>0,05$ ), sedangkan variabel responsiveness, assurance signifikan

terhadap kepuasan publik karena nilainya $(<0,05)$.

\section{Analisa Pengujian Hipotesis dan Korelasi}

Uji $\mathrm{F}$ berguna untuk menentukan apakah model penaksiran yang kita gunakan tepat atau tidak, dilihat dari hasil penelitian nilai uji $\mathrm{F}$ adalah 13,368 pada alpa 5\% dapat disimpulkan bahwa nilai 13,368 yang berarti variasi perubahan yang terjadi pada variabel tangible, empathy,

reliability, responsiveness, assurance, maka model ini dapat digunakan dengan tepat. Nilai signinifikan nyata apabila nilai tersebut $(<0,05)$ dari hasil penelitian nilai $(\mathrm{Sig})$ adalah $0,00<0,05$ berarti model regresi dapat diterima, karena semakin tinggi kualitas pelayanan maka semakin tinggi tingkat kepuasan publik. Nilai R Square (koofisien determinasi) dari hasil penelitian adalah55.3\%, artinya 55,3 \% kepuasan publik dipengaruhi oleh kualitas pelayanan dan $44,7 \%$ variabel kepuasan publik dipengaruhi oleh faktor lain yang diteliti, seperti gaya kepemimipinan atasan.

Setelah menguji hipotesis dengan regresi linear berganda didapatkan hasil yang menyatakan bahwa ada pengaruh antara tangible, empathy. reliability, responsiveness, assuranceterhadap kepuasan publik.

Uji t berguna untuk menguji signifikan antara variabel kualitas pelayanan berpengaruh secara nyata terhadap kepuasan publik. Berdasarkan tabel 4.15 yaitu $t$ hitung untuk tangible sebesar 1,233 dinyatakan ada pengaruh antara tangible dengan kepuasan publik, t hitung untuk empathy sebesar 1,497 dapat dinyatakan ada pengaruh antara emphathy dengan kepuasan publik, t hitung untuk reliability sebesar 0,220 dapat dinyatakan ada pengaruh reliability dengan kepuasan publik, sedangkan thitung untuk responsiveness sebesar 2,439 dapat dinyatakan ada pengaruh antara responsiveness dengan kepuasan publik, t hitung untuk assurance sebesar 2,595 dapat dinyatakan ada pengaruh antara assurance dengan kepuasan publik.

Nilai dinyatakan reliable jika nilai cronbach's Alpha $>0,70$. Nilaicronbach's Alpha dimensi tangible $(0,808)$, empathy $(0,852)$, reliability $(0,852)$, Responsiviness $(0,801)$ dan assurance $(0,778)$. Jadi semua variable kualitas pelayanan reliable dalam mengukur kepuasan publik.

Nilai signifikan $(<0,05)$, berdasarkan penelitian diatas bahwa variabel (tangible, emphaty, reliability) tidak signifikan terhadap kepuasan publik karena besar dari $(0,05)$, sedangkan variabel (responsiveness, assurance) signifikan terhadap kepuasan publik karena nilai (sig <0,05).

Dimensi tangible tidak signifikan dilihat dari item kuesioner semua yang berhubungan dengan wujud yaitu peralatan, fasilitas, penampilan, dan bahan-bahan yang berkaitan dengan informasi tidak menarik untuk dibaca.Jadi diharapkan untuk lebih ditingkatkan lagi untuk kelancaran dalam pengurusan izin, sehingga publik mendapatkan kepuasan dalam pengurusan izin.

Dimensi Empathy tidak signifikan karena dilihat dari item kuesioner publik kurang merasakan kemudahan dalam 
hal dalam melakukan hubungan komunikasi yang baik, perhatian pribadi, dan tidak memahami kebutuhan dan keinginan publik. Oleh karena itu, sebaiknya pegawai Badan Pelayanan Perizinan Terpadu, Pengadaan Barang dan Jasa harus meningkatkannya supaya tercapainya kepuasan publik.

Dimensi Reliability tidak signifikan karena di lihat dari item kuesioner publik tidak merasakan kehandalan pegawai Badan Pelayanan Perizinan Terpadu, Pengadaan Barang dan Jasa dalam menepati janji layanan secara cepat, akurat, dan memuaskan. Maka ini harus diperhatikan karena hasil yang cepat dan akurat sangat berpengaruh terhadap kepuasan publik.

Dimensi Responsiveness signifikan terhadap kepuasan publik karena pegawai pada Badan Pelayanan Perizinan Terpadu, Pengadaan Barang dan Jasa bisa memberikan ketanggapan dalam membantu publik dalam memberikan pelayanan pengurusan perizinan.

Dimensi Assurance signifikan karena pegawai Badan Pelayanan Perizinan Terpadu, Pengadaan Barang dan Jasa bisa memberikan keyakinan kepada publik dalam memberikan informasi yang tepat sehingga mereka menemukan bahwa dalam pengurusan perizinan pada Badan Pelayanan Perizinan Terpadu, Pengadaan Barang dan Jasa mudah, transparan, aman, nyaman, dan selalu bersikap sopan (konsisten) dalam menjawab pertanyaan yang diajukan publik.

Jadi berdasarkan hasil penelitian regresi linear berganda kualitas pelayanan perpengaruh terhadap kepuasan publik karena koofisien regresi masing-masing variabel kualitas pelayanan positif atau proporsional, tetapi dilihat dari nilai (sig) dimensi (tangible, Empathy, Reliability) tidak signifikan terhadap kepuasan publik dalam pengurusan perizinan sedangkan dimensi (Responsiveness dan Assurance) signifikan terhadap kepuasan publik dalam pengurusan perizinan.Dengan demikian hal ini sangat penting, artinya walaupun didalam instansi pemerintahan tidak adanya persaingan terhadap kepuasan publik kualitas pelayanan harus ditingkatkan untuk mencapai kepuasan publik. Oleh karena itu, Aparatur pemerintah harus meningkatkan kualitas pelayanan ini, dimana semakin tinggi tingkat kualitas pelayanan maka semakin tinggi pula tingkat kepuasan publik dalam pengurusan perizinan.

\section{SIMPULAN DAN IMPLIKASI}

Berdasarkan hasil penelitian yang telah dilakukan tentang pengaruh kualitas jasa (dimensi tangible, empathy, realibility, responsiveness, dan assurance) terhadap kepuasan publik dalam pengurusan perizinan di Kabupaten Dharmasraya dengan menggunakan sampel 60 orang, dapat diambil kesimpulan bahwa :

1. Kualitas jasa berpengaruh terhadap tingkat kepuasan publik. Artinya dengan peningkatan variabel tersebut akan meningkatkan nilai positif pada publik lain dalam pengurusan perizinan pada Badan Pelayanan Perizinan Terpadu, Pengadaan Barang dan Jasa.

2. Hasil penelitian ini menunjukkan bahwa dimensi tangible, empathy, reliability tidak signifikanterhadap kepuasan publik karena nilai signifikannya $>0,05$. Sedangkan dimensi responsiveness dan assurance signifikan terhadap kepuasan publik dalam pengurusan perizinan karena nilai signifikan $<0,05$. Artinya kualitas jasa perlu ditingkatkan untuk mencapai kepuasan publik baik secara langsung maupun tidak langsung.

3. Dilihat dari hasil uji reliabilitasapabila nilai cronbach's Alpha nya $>0,70$ maka dinyatakan (reliable). Nilai dimensi tangible sebesar $(0,808)$, empathy sebesar 
$(0,852)$, reliability sebesar $(0,852)$, responsiveness sebesar $(0,801)$ dan assurance $(0,778)$. Maka dimensi empathy dan reliability merupakan dimensi yang paling dominan mempengaruhi kepuasan publik dalam pengurusan perizinan.

4. Berdasarkan hasil penelitian puas atau tidaknya masyarakat dalam pengurusan izin pada Badan Pelayanan Perizinan Terpadu, Pengadaan Barang dan Jasa, mereka harus mengurus izin Surat Izin Tempat Usaha (SITU) tersebut karena membutuhkannya. Sehingga variabel kualitas pelayanan yang diteliti berpengaruh terhadap kepuasan publik dalam pengurusan perizinan.

Untuk meningkatkan nilai kualitas pelayanan terhadap kepuasan publik atas dimensi kualitas jasa pada Badan Pelayanan Perizinan Terpadu, Pengadaan Barang dan Jasa Kabupaten Dharmasraya harus melakukan langkah-langkah strategis dengan cara memahami harapan dan keinginan publik. Untuk itu rekomendasi yang di sampaikan kepada Badan Pelayanan Perizinan Terpadu, Pengadaan Barang dan Jasa berkenaan dengan kesimpulan diatas adalah :

1. Atasan Badan Pelayanan Perizinan Terpadu, Pengadaan Barang dan Jasa perlu secara rutin mengamati pegawainya agar dapat mempertahankan kelebihankelebihan yang ada dan selalu meningkatkan kualitas pelayanan pada variabelvariabel yang masih kurang penilaiannya menurut publik. Hal ini bisa dilakukan lebih memperhatikan kebutuhan atau keinginan publik, peningkatan sarana dan prasarana, jaminan rasa aman, nyaman, dan kepercayaan serta pelayanan yang dijanjikan secara cepat, akurat dan pasti sehingga dapat meningkatkan kepuasan publik

2. Perangkat Daerah Badan Pelayanan Perizinan Terpadu, Pengadaan Barang dan Jasa sebaiknya menyediakan kotak saran untuk dapat mengetahui hal apa saja yang menjadi keluhan publik. Dengan demikian Badan Pelayanan Perizinan Terpadu, Pengadaan Barang dan Jasa akan dapat mempertahankan kualitas pelayanan dan meningkatkannya.

3. Semua unsur dimensi kualitas pelayanan diatas mempunyai pengaruh positif terhadap kepuasan publik, tetapi variabel variabel (tangible, Empathy, Reliability) tidak siginifikan terhadap kepuasan publik dalam pengurusan perizinan, sedangkan variabel (Responsiveness dan Assurance) signifikan terhadap kepuasan publik dalam pengurusan perizinan pada Badan Pelayanan Perizinan Terpadu, Pengadaan Barang dan Jasa, artinya ini harus diperhatikan secara khusus dalam meningkatkan nilai dimensi-dimensi kualitas pelayanan dan mencari solusi yang baru untuk dapat meningkatkan kepuasan publik.

\section{DAFTAR PUSTAKA}

Achmad Batinggi (2007), Manajemen Pelayanan Umum, Jakarta : Universitas Terbuka.

Anderson, (1972), A. Revision of Bloom's Texonomy of Education objectives, Edisi yang dipadatkan.Newyork. Addison Wesley Longman.

Arikunto, (1997).Prosedur Penelitian Suatu Pendekatan Praktek. Jakarta : Rineka Cipta.

Engel,(1995), Straregi Menaklukkan Pasar Melalui Riset Ekuitas dan Perilaku Merek. Goes dan Davis dalam Tjiptono, (2004), Manajemen Jasa, Yogyakarta. Andi. 
Hasibuan, Malayu S.P (2005), Manajemen Sumber Daya Manusia, PT Bumi Aksara, Jakarta.

Kotler, Philip (1999). Manajemen Pemasaran, Analisis Perencanaan, Implementasi dan Kontrol (jilid 1 dan 2).Terjemahan Hendra Teguh dan Ronny A. Rusli, PT. Prenhallindo, Jakarta.

Kotler dan Amstrong, (2001).Prinsip-Prinsip Pemasaran. Jilid Pertama Edisi Kedelapan. Jakarta : Erlangga

Lupiyoadi dan Hamdani (2006), Manajemen Pemasaran Jasa, Penerbit Salemba Empat, Jakarta.

Lupiyoadi Rambat,(2001). Manajemen Pemasaran Jasa. Penerbit Salemba Empat, Jakarta.

Parasuraman, A.Zeithaml (2000), Delivering Quality Service, New York:the Fre Press A division of Macmillan. Inc.

Rangkuti, (2002), Measuring Customer Satiscaftion. Yogyakarta. Gramedia Pustaka Utama.

Sekaran,(2003) Reliability is the consistency and of the measuring instrument.

Sugiono,dkk (2002), Teknik sampling, Gramedia Pustaka Utama, Jakarta.

Sugiyono, (2004), Metode Penelitian Bisnis. Cetakan Keenam. Bandung : CV. Alfabeta.

Tjiptono, (2004).Service Quality and Satisfaction.Yogyakarta.Penerbit Andi, Yogyakarta.

Tjiptono, (2000), 5 Faktor Menentukan Kualitas Jasa, Media Komputindo, Jakarta.

Tjiptono, (2004), Strategi Pemasaran. Edisi Kedua. Yogyakarta : Andi Offset.

Tjiptono, (2004), Manajemen Pemasaran Jasa. Yogyakarta ; Andi Offset 